\title{
Purification and Characterization of the Outer Membrane Associated Alkaline Phosphatase of Lysobacter enzymogenes
}

\author{
By RICHARD G. VON TIGERSTROM* AND SHEILAH STELMASCHUK \\ Department of Microbiology, University of Alberta, Edmonton, Canada T6G 2E9
}

(Received 16 July 1985 ; revised 26 November 1985)

The alkaline phosphatase (EC 3.1.3.1) associated with the outer membrane of Lysobacter enzymogenes was solubilized from a crude membrane preparation with detergent and purified 219-fold using ion-exchange chromatography and gel filtration. The yield of the purified enzyme was $21 \%$ and the specific activity was 438 units $\mathrm{mg}^{-1}$. The enzyme was most active at $\mathrm{pH} 8.5$, readily hydrolysed $5^{\prime}$-, 2'- and $3^{\prime}$-ribose and deoxyribose nucleotides, glucose 6-phosphate, glycerophosphates and p-nitrophenylphosphate and was strongly inhibited by EDTA and 8hydroxyquinoline. The EDTA-inhibited enzyme could be reactivated to some extent by $\mathrm{CoCl}_{2}$ and more effectively by $\mathrm{ZnCl}_{2}$. The phosphatase was slightly activated by $p$-nitrophenylphosphate and from kinetic studies using this substrate two $K_{\mathrm{m}}$ values, $0.56 \times 10^{-4} \mathrm{M}$ and $3.4 \times 10^{-4} \mathrm{M}$, were estimated. The enzyme retained activity in the presence of SDS, unless it was heated, and had an apparent $\boldsymbol{M}_{\mathrm{r}}$ of 69000 , as determined by SDS-PAGE. Gel filtration data suggested that the native enzyme might consist of at least two subunits. The properties of the enzyme were consistent with the view that it is held in the outer membrane by hydrophobic interactions.

\section{INTRODUCTION}

Species of the genus Lysobacter are Gram-negative, non-fruiting, gliding bacteria which share many physiological characteristics with the Myxobacteria (Christensen \& Cook, 1978; Reichenbach, 1981; Reichenbach \& Dworkin, 1981). Lysobacter enzymogenes produces a number of extracellular enzymes (Whitaker, 1970; Christensen \& Cook, 1978; von Tigerstrom, $1980,1981,1983,1984)$, including two phosphatases. One of these phosphatases has been described in detail (von Tigerstrom, 1984). It is produced and excreted into the medium soon after the exponential growth phase. It has an $M_{\mathrm{r}}$ of about 25000 , is most active at $\mathrm{pH} 7.5$ and is insensitive to inhibition by EDTA. The other phosphatase is produced during the exponential and early stationary growth phases and remains tightly associated with the cells. This enzyme is hydrophobic, is most active at $\mathrm{pH} 8.5$ and is sensitive to inhibition by chelating agents (von Tigerstrom, 1984). Thus, the two phosphatases are clearly distinct. Recently the cell-associated phosphatase of $L$. enzymogenes was located in the outer membrane of the organism (von Tigerstrom \& Stelmaschuk, 1985).

It is hoped that an investigation of the properties of the cell-associated phosphatase and of how this enzyme interacts with other outer membrane components will lead to a better understanding of the cell surface of $L$. enzymogenes, and of gliding bacteria in general. This paper describes the purification and characterization of the phosphatase associated with the outer membrane.

\section{METHODS}

Chemicals. The sources of most of the chemicals used during the purification and characterization of the phosphatase have been reported (von Tigerstrom, 1984). In addition, DEAE-Sephacel and Sephacryl S-200 were

Abbreviation: pNPP, p-nitrophenylphosphate. 
obtained from Pharmacia and Zwittergent 3-14 from Calbiochem-Behring. The other detergents, the substrates used for the enzyme assays and the heparin-agarose were from Sigma. The $M_{\mathrm{r}}$ standards used for PAGE were from Pierce, except for phosphorylase $b$, which was purchased from Sigma.

Organism, medium and culture conditions. Lysobacter enzymogenes UASM 495 (ATCC 29487) was grown aerobically in $0.8 \%$ peptone broth as described previously (von Tigerstrom, 1984). The cells grew to an $\mathrm{OD}_{600}$ of about 2.4 and were harvested in the stationary phase by centrifugation at $16300 \mathrm{~g}$ for $15 \mathrm{~min}$. Tryptone broth, used in previous studies, was not used here since in this medium the growth and the production of some extracellular enzymes were not reproducible.

Enzyme assays. For routine assays the enzyme sources were diluted into $10 \mathrm{~mm}-\mathrm{Tris} / \mathrm{HCl}, 50 \mathrm{~mm}-\mathrm{NaCl}, 1.5 \mathrm{mM}-$ $\mathrm{MgCl}_{2}, 0.2 \% \mathrm{Zwittergent} 3-14, \mathrm{pH} 7 \cdot 5$. The phosphatase assay for the cell-associated enzyme was done as previously described (von Tigerstrom, 1984), except that $4 \mathrm{~mm}$-p-nitrophenylphosphate (pNPP) was used. One unit of phosphatase is the amount that hydrolyses $1 \mu \mathrm{mol}$ substrate $\min ^{-1}$ at $37^{\circ} \mathrm{C}$. For the determination of $K_{\mathrm{m}}$, 0.05 to $15 \mathrm{~mm}$-pNPP was used. The activity of the enzyme with different substrates was compared by diluting the enzyme without detergent and using assay solutions with $0.15 \mathrm{M}$-triethanolamine, $0.2 \%$ Triton X-100 and $4 \mathrm{mM}$ substrate, adjusted to $\mathrm{pH} \mathrm{8.5} \mathrm{with} \mathrm{HCl}$. Zwittergent 3-14 was replaced by Triton X-100 because it interfered with the phosphate assay. The rates of hydrolysis were estimated from the inorganic phosphate released after 3,10 and 20 min incubation at $37^{\circ} \mathrm{C}$.

The procedure for the determination of phosphatase activities at different $\mathrm{pH}$ values has been described (von Tigerstrom, 1984).

The effect of phosphate on the heat inactivation of the enzyme was determined at $60{ }^{\circ} \mathrm{C}$. The phosphatase was added to $10 \mathrm{mM}$-Tris/ $\mathrm{HCl}, 50 \mathrm{mM}-\mathrm{NaCl}, 1.5 \mathrm{mM}-\mathrm{MgCl}_{2}, 0.2 \%$ Zwittergent $3-14, \mathrm{pH} 7.4$ with or without $5 \mathrm{mM}$ potassium phosphate, $\mathrm{pH} 7 \cdot 4$. At intervals samples were removed and diluted 10-fold for the routine assay of the enzyme. The final phosphate concentration in the enzyme assay was $0.05 \mathrm{mM}$, which has little or no effect on the phosphatase activity.

The effect of inhibitors on the enzyme activity was determined by incubating the enzyme in the assay solution without pNPP for $10 \mathrm{~min}$ at $37^{\circ} \mathrm{C}$ and then starting the assay by the addition of the substrate.

The reactivation of enzyme, which had been inhibited by EDTA, was studied by preincubating the enzyme in $10 \mathrm{~mm}$-Tris/ $\mathrm{HCl}, 50 \mathrm{~mm}-\mathrm{NaCl}, 0.2 \%$ Zwittergent $3-14,0.2 \mathrm{~mm}$-EDTA, pH 7.5, for $10 \mathrm{~min}$ at $37^{\circ} \mathrm{C}$. Enzyme solution $(50 \mu \mathrm{l})$ was then added to $0.45 \mathrm{ml}$ of the assay solution containing the metal ion $(0.05 \mathrm{~mm}$ final concentration).

Polyacrylamide gel electrophoresis. Conditions for PAGE of the phosphatase have been described in detail (Maizel, 1971; von Tigerstrom, 1984). Samples were prepared under the usual denaturing conditions for the detection of protein (Fairbanks et al., 1971) and prepared in $10 \mathrm{mM}-\mathrm{Tris} / \mathrm{HCl}, 1 \% \mathrm{SDS}, \mathrm{pH} 8.0$, without heating for the detection of phosphatase activity (von Tigerstrom \& Stelmaschuk, 1985).

Analytical methods. Protein concentrations were determined by the Lowry method and by absorbance (Warburg \& Christian, 1941). Phosphate concentrations were determined by the method of Ames (1966).

Purification of the enzyme. Trial purifications from a relatively small culture were then scaled up to 61 and 81 of culture. These gave very similar results and the purification of the phosphatase from the 81 culture is described in detail. All operations were done at 0 to $4^{\circ} \mathrm{C}$ unless otherwise indicated. The enzyme was concentrated at various stages of the purification by ultrafiltration using an Amicon PM 10 membrane.

Step I. Preparation of cell-free extract. L. enzymogenes cells $(50 \mathrm{~g}$ wet weight) were washed by centrifugation $(10 \mathrm{~min}$ at $15300 \mathrm{~g})$ and resuspension in $20 \mathrm{mM}-\mathrm{Tris} / \mathrm{HCl}, 1 \mathrm{mM}-\mathrm{MgCl}_{2}, \mathrm{pH} \mathrm{7.5}$, resuspended in $225 \mathrm{ml}$ buffer and disrupted in a French pressure cell at $103 \mathrm{MPa}$. The suspension was diluted to $800 \mathrm{ml}$ with the same buffer and intact cells were removed by centrifugation at $3100 \mathrm{~g}$ for $15 \mathrm{~min}$ to obtain $777 \mathrm{ml}$ cell-free extract.

Step II. Preparation of the $48000 \mathrm{~g}$ pellet and solubilization. The cell-free extract was centrifuged at $48000 \mathrm{~g}$ for $60 \mathrm{~min}$, the supernatant was discarded and the pellet was suspended in $10 \mathrm{mM}-\mathrm{Tris} / \mathrm{HCl}, \mathrm{pH} 7 \cdot 5$, to yield about $400 \mathrm{ml}$ of suspension. Zwittergent 3-14 was added to a final concentration of $0 \cdot 2 \%$. The suspension was stirred for $60 \mathrm{~min}$ and then left for $18 \mathrm{~h}$. Centrifugation at $27000 \mathrm{~g}$ for $15 \mathrm{~min}$ yielded the solubilized enzyme preparation containing $83 \%$ of the phosphatase activity; the pellet was discarded.

Step III. Adsorption to DEAE-Sephacel. Wet DEAE-Sephacel in the acetate form $(370 \mathrm{~g})$ was added to the solubilized enzyme. The suspension was stirred for $30 \mathrm{~min}$ and then left overnight. The ion-exchanger was packed into a column $(5 \times 22 \mathrm{~cm})$, eluted with $200 \mathrm{ml} 10 \mathrm{mM}$-Tris/acetate, $\mathrm{pH} 7 \cdot 5$, and then with $10 \mathrm{~mm}$-Tris/acetate, $0.3 \mathrm{M}$-ammonium acetate, $0.05 \%$ Zwittergent 3-14, $\mathrm{pH} 7.5,17 \mathrm{ml}$ fractions being collected. Three peaks were obtained. The run-off peak contained about $4 \%$ of the enzyme applied and almost half the protein, and the second peak contained most of the enzyme in approx. $500 \mathrm{ml}$. This was concentrated to $182 \mathrm{ml}$ by ultrafiltration. A third, trailing peak, containing about $24 \%$ of the phosphatase activity, was not included for further purification.

Step IV. DEAE-Sephacel chromatography. This step was done at $8^{\circ} \mathrm{C}$. The active fraction obtained above was dialysed against $10 \mathrm{mM}-\mathrm{Tris} / \mathrm{HCl}, 10 \mathrm{mM}-\mathrm{NaCl}, 1 \mathrm{mM}-\mathrm{MgCl}_{2}, 0.05 \%$ Zwittergent 3-14, $\mathrm{pH} 7.5$ (starting buffer 1) and applied to a column of DEAE-Sephacel $(5 \times 31 \mathrm{~cm})$ pre-equilibrated with the same buffer. The column was then eluted with $280 \mathrm{ml}$ starting buffer 1 and a gradient consisting of $1400 \mathrm{ml}$ starting buffer 1 and $1400 \mathrm{ml} 10 \mathrm{~mm}$ - 
Tris/ $\mathrm{HCl}, 0.6 \mathrm{M}-\mathrm{NaCl}, 1 \mathrm{~mm}-\mathrm{MgCl}_{2}, 0.05 \%$ Zwittergent $3-14, \mathrm{pH} 7.5,15 \mathrm{ml}$ fractions being collected. The phosphatase activities, the $A_{280}$ values and the conductivities were determined. Fractions $92-107$ were pooled and concentrated to $78 \mathrm{ml}$ by ultrafiltration.

Step $V$. Heparin-agarose chromatography. The phosphatase obtained in the previous step was dialysed against $10 \mathrm{mM}-\mathrm{MES}$, pH 5.5, and applied to a heparin-agarose column $(2.5 \times 31 \mathrm{~cm})$ equilibrated with $10 \mathrm{mM}-\mathrm{MES}, 0.05 \%$ Zwittergent 3-14, pH $5 \cdot 5$ (starting buffer 2). The column was eluted at $8^{\circ} \mathrm{C}$ with $200 \mathrm{ml}$ starting buffer 2 and then with a gradient consisting of $500 \mathrm{ml}$ starting buffer 2 and $500 \mathrm{ml} 10 \mathrm{mM}-\mathrm{MES}, 0.3 \mathrm{M}-\mathrm{KCl}, 0.05 \% \mathrm{Zwittergent} 3-14$, pH $5.5,11.6 \mathrm{ml}$ fractions being collected. The phosphatase activities, the $A_{280}$ values and the conductivities were determined. Fractions $52-62$ were pooled and concentrated to $8 \mathrm{ml}$ by ultrafiltration.

Step VI. Gel filtration. The phosphatase preparation was applied to a Sephacryl S-200 column $(2.6 \times 96.5 \mathrm{~cm})$ equilibrated with $10 \mathrm{~mm}$-Tris $/ \mathrm{HCl}, 0.1 \mathrm{M}-\mathrm{NaCl}, 1 \mathrm{~mm}-\mathrm{MgCl}_{2}, 0.1 \% \mathrm{Brij} 58, \mathrm{pH} 7 \cdot 5$, and eluted with the same buffer, $5.4 \mathrm{ml}$ fractions being collected. The phosphatase activities and the $A_{280}$ values were determined. Fractions $36-42$ were pooled and concentrated to $12.9 \mathrm{ml}$.

To ensure the complete removal of the ionic detergent Zwittergent 3-14 from the enzyme preparation, the phosphatase was reapplied, after dialysis against $10 \mathrm{mM}-\mathrm{Tris} / \mathrm{HCl}, 10 \mathrm{mM}-\mathrm{NaCl}, 1 \mathrm{mM}-\mathrm{MgCl}, \mathrm{pH} 7 \cdot 5$, to a smaller DEAE-Sephacel Column $(2.5 \times 25 \mathrm{~cm})$ and eluted with the buffers described above (step IV), except that the Zwittergent 3-14 was replaced with 0.1\% Brij 58 and proportionally smaller buffer volumes were used. Approximately $91 \%$ of the phosphatase applied to this column was recovered with only a slight increase in the specific activity.

\section{RESULTS}

\section{Purification of the cell-associated phosphatase}

The results of the purification procedure described in Methods are summarized in Table 1. After preparation of the cell-free extract the enzyme was sedimented with other particulate components by centrifugation. It then was solubilized with Zwittergent 3-14. Preliminary results had shown that the presence of a detergent was essential for the efficient elution of the enzyme during column chromatography. Only $8 \%$ of the enzyme was recovered from the column if the detergent was omitted. Zwittergent 3-14, which was particularly efficient in solubilizing the phosphatase, was therefore present in the buffers used in steps II to $\mathrm{V}$ of the procedure.

DEAE-Sephacel was used at two stages, the first time being for batchwise adsorption of the enzyme and elution by increased salt concentration. A considerable amount of activity $(24 \%)$ was eluted after the main peak. Although the enzyme in this peak was excluded from further purification, subsequent experiments indicated that the two peaks contained the same enzyme. After dialysis of the enzyme from both peaks and reapplication to DEAE-Sephacel the material eluted in a sharp single peak at $0.165 \mathrm{M}-\mathrm{NaCl}$. Furthermore, material from both peaks had identical electrophoretic mobilities in a polyacrylamide gel. Therefore, it appears that the double peak in step III was an artifact of the batchwise chromatography.

A six-fold purification was obtained in step IV, the gradient elution of the enzyme from DEAE-Sephacel (Fig. 1a) and nearly a four-fold purification in step V, the heparin-agarose chromatography (Fig. $1 b$ ). Chromatography on heparin-agarose routinely caused a substantial

Table 1. Purification of the cell-associated phosphatase

The enzyme was purified as described in Methods. Volumes have been corrected for removal of samples for activity and protein determination.

$\begin{array}{lcccc}\text { Total } & \begin{array}{c}\text { Total } \\ \text { protein } \\ \text { (mg) }\end{array} & \begin{array}{c}\text { Specific } \\ \text { activity } \\ \text { (units) }\end{array} & \begin{array}{c}\text { activity } \\ \text { [units (mg } \\ \text { protein) }\end{array} & \begin{array}{c}\text { Purification } \\ \text { (fold) }\end{array} \\ \text { Purification step } & 4700 & 9522 & 2 & - \\ \text {-free extract } & 1817 & 7862 & 4 \cdot 3 & 2 \cdot 2 \\ \text { A g pellet and solubilization } & 598 & 4568 & 7 \cdot 6 & 3.8 \\ \text { AE-Sephacel 1 } & 92 & 4309 & 46 \cdot 8 & 23 \cdot 4 \\ \text { AE-Sephacel 2 } & 12 \cdot 8 & 2282 & 178 \cdot 3 & 89 \cdot 2 \\ \text { harin-agarose } & 4.5 & 1973 & 438 \cdot 4 & 219 \cdot 2\end{array}$

I. Cell-free extract

II. $48000 \mathrm{~g}$ pellet and solubilization

III. DEAE-Sephacel 1

IV. DEAE-Sephacel 2

V. Heparin-agarose

VI. Sephacryl S-200
$438 \cdot 4$ 

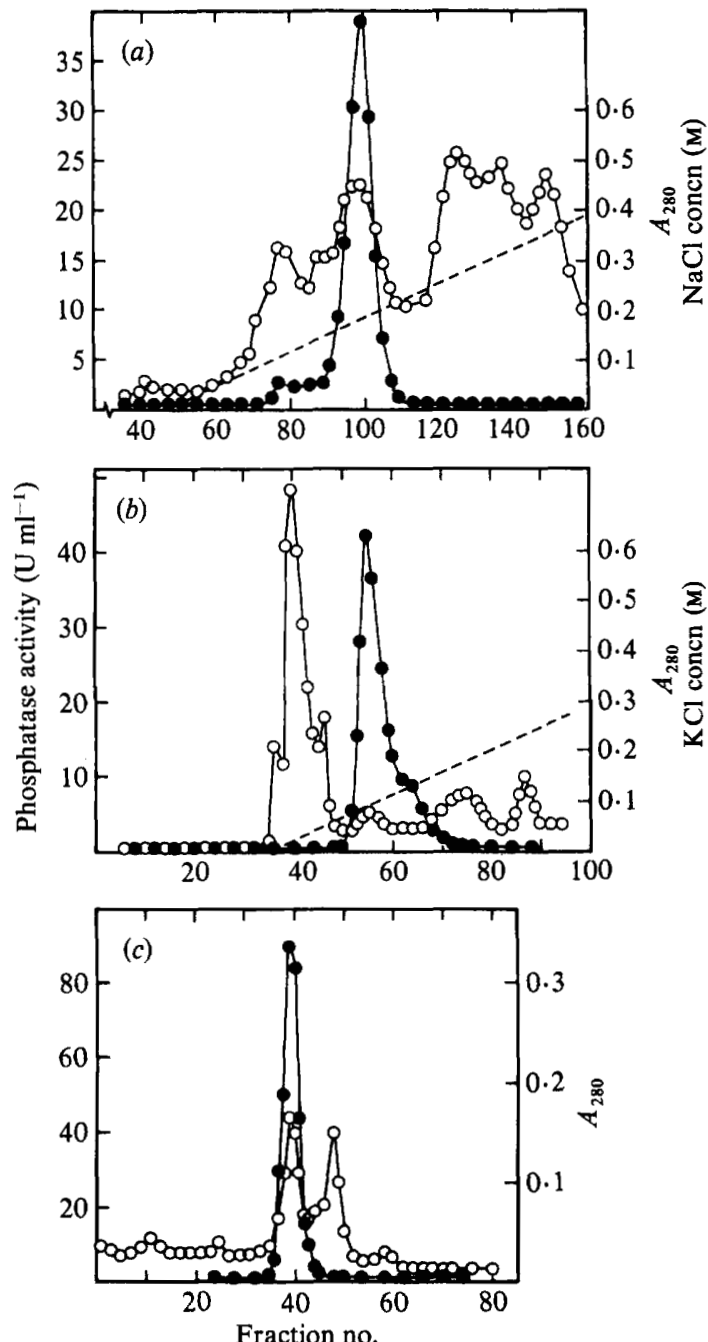

Fig. 1. Purification of the cell-associated phosphatase by DEAE-Sephacel chromatography $(a)$, heparin-agarose chromatography $(b)$ and Sephacryl S-200 gel filtration $(c)$ as described in Methods (purification steps IV, V and VI). The phosphatase activities $(\bullet)$, the $A_{280}(O)$ and the salt concentrations (---) were determined.

loss of the enzyme activity. The low pH may have been a factor, although the enzyme is quite stable when stored at $\mathrm{pH} 5 \cdot 5$.

The last step of the purification, the gel filtration (Fig. 1c), was done with a buffer, in which Brij 58 replaced the ionic detergent Zwittergent 3-14, which might have interfered with the electrophoresis and further characterization of the phosphatase. Similar results were obtained, however, when Zwittergent 3-14 or deoxycholate was used during gel filtration.

The final product of the purification procedure contained only minor impurities as judged by PAGE. The phosphatase was purified over 200-fold to a specific activity of 438 units (mg protein) $)^{-1}$ and with a $21 \%$ yield.

\section{$P A G E$ and $M_{r}$ determination}

Electrophoresis was done in $10 \%$ gels containing $0 \cdot 1 \%$ SDS. Enzyme samples were treated in two different ways before application: for the detection of protein bands and the $M_{\mathrm{r}}$ estimation 


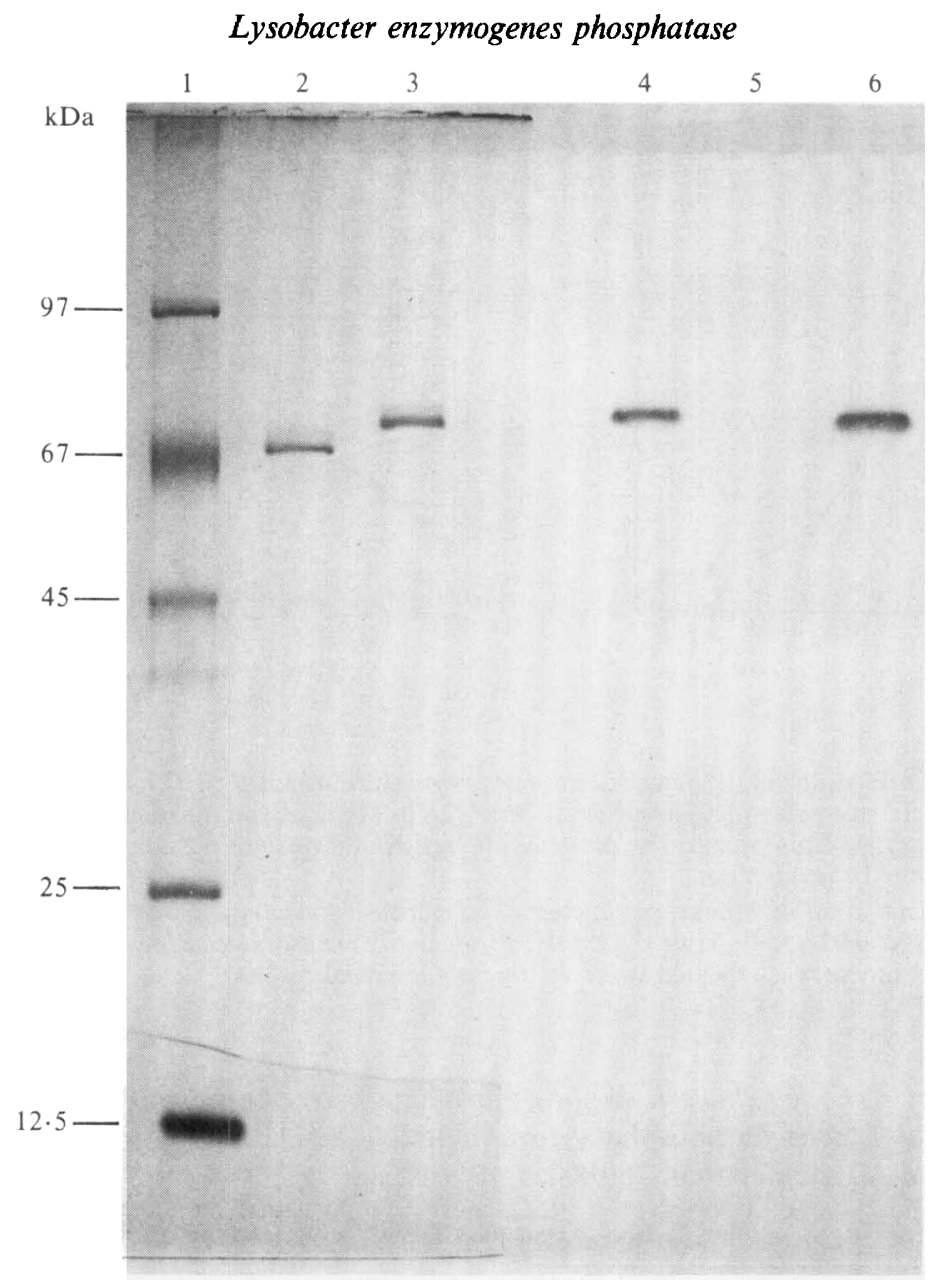

Fig. 2. Polyacrylamide gel electrophoresis. The following were subjected to electrophoresis in a $10 \%$ (w/v) polyacrylamide gel with $0 \cdot 1 \%$ SDS. Lane $1, M_{\mathrm{r}}$ standards (phosphorylase $b$, serum albumin, ovalbumin, chymotrypsinogen and cytochrome $c)$; lanes 2 and $3,1.03 \mu \mathrm{g}(0.6$ units) purified phosphatase; lanes 4 and $5,0.021 \mu \mathrm{g}(0.012$ units) purified phosphatase; lane $6,0.053 \mu \mathrm{g}(0.03$ units $)$ purified phosphatase. Samples in lanes 1, 2 and 5 were heat-denatured in the presence of $1 \%$ SDS and 2mercaptoethanol. Samples in lanes 3,4 and 6 were treated only with $1 \%$ SDS. Lanes 1,2 and 3 were stained with Coomassie blue and lanes 4,5 and 6 were subjected to the phosphatase activity stain. The results were very reproducible.

the enzyme was heat-denatured in the usual manner with SDS and 2-mercaptoethanol (Maizel, 1971); whereas for detection of enzymic activity, the enzyme was applied after the addition of only SDS and was not heated (Fig. 2). The heat-denatured preparation showed one major protein band with an apparent $M_{\mathrm{r}}$ of 69000 . Without the heat treatment one major protein band, which coincided with one major activity band of apparent $M_{\mathrm{r}} 76000$, was visible if the enzyme was applied at a low concentration. If the amount of enzyme applied was increased five-fold or more, both the protein stain and the activity stain resulted in two closely spaced bands. This may have been due to overloading, the hydrophobic nature of the protein or incomplete denaturation under these conditions.

PAGE without detergent or in the presence of Triton X-100 or Brij 58 was not successful since the protein penetrated the gel very poorly.

An attempt was also made to estimate the native $M_{\mathrm{r}}$ of the enzyme by gel filtration using Sephacryl S-200 with a buffer system containing $0.1 \%$ deoxycholate. Blue dextran, 


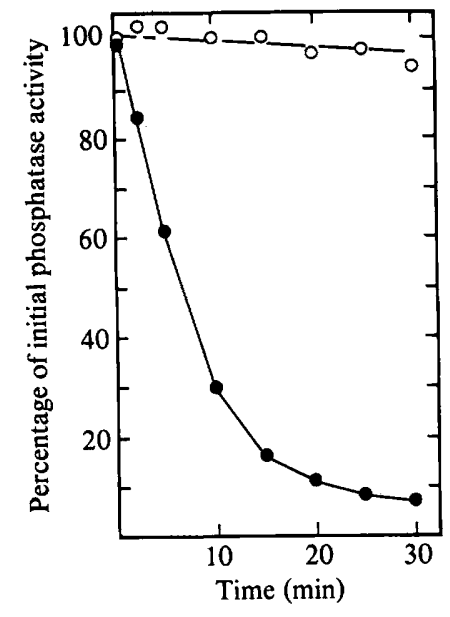

Fig. 3

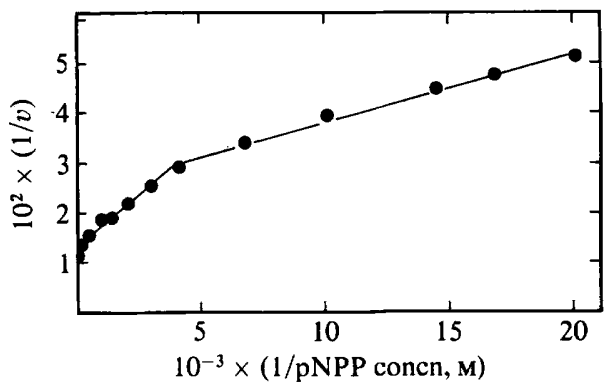

Fig. 4

Fig. 3. Heat inactivation of the phosphatase. The enzyme was heated at $60^{\circ} \mathrm{C}$ in the presence (O) and absence $(\mathrm{O})$ of $5 \mathrm{mM}$-potassium phosphate as described in Methods and the remaining activities were determined over a $30 \mathrm{~min}$ period. The presence of $5 \mathrm{mM}-\mathrm{KCl}$ instead of potassium phosphate did not increase the rate of inactivation.

Fig. 4. Determination of kinetic parameters. The purified phosphatase was assayed with pNPP concentrations of $0.05 \mathrm{mM}$ to $15 \mathrm{mM}$ and kinetic parameters were estimated using the double reciprocal plot. The experiment was repeated twice with nearly identical results.

immunoglobulin G, Escherichia coli alkaline phosphatase, ovalbumin and RNAase A were used as standards. The Lysobacter phosphatase was eluted at a position before the immunoglobulin $\mathrm{G}$, indicating an $M_{\mathrm{r}}$ greater than 150000 .

\section{Stability and solubility}

The phosphatase was stable, at least for several weeks, at $-22^{\circ} \mathrm{C}$ in $10 \mathrm{~mm}$-Tris/ $\mathrm{HCl}, 50 \mathrm{~mm}$ -

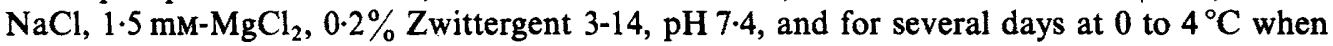
stored at pH 5.5 to 8.0 in $20 \mathrm{mM}$-Tris/acetate buffer. The enzyme could be incubated with $1 \%$ SDS for several hours at room temperature without significant loss of activity, but appeared to be irreversibly inactivated after heating $\left(97^{\circ} \mathrm{C}, 10 \mathrm{~min}\right)$ in the presence of $1 \%$ SDS and $0.1 \% 2-$ mercaptoethanol (Fig. 2). At $60{ }^{\circ} \mathrm{C}$ the enzyme was stable for at least $20 \mathrm{~min}$, while only $70 \%$ and $2 \%$ of the activity remained after heating at $70{ }^{\circ} \mathrm{C}$ for $10 \mathrm{~min}$ and $20 \mathrm{~min}$, respectively. The rate of inactivation at elevated temperatures was increased significantly by the presence of $5 \mathrm{mM}$ potassium phosphate (Fig. 3). In a similar experiment $85 \%$ of the excreted phosphatase of $L$. enzymogenes was inactivated after $60 \mathrm{~min}$ at $65^{\circ} \mathrm{C}$ but, in contrast to the cell-associated enzyme, it was completely stabilized at this temperature by the addition of $5 \mathrm{~mm}$-potassium phosphate.

The degree of solubilization of the enzyme by different detergents was determined. The $48000 \mathrm{~g}$ pellet from the cell-free extract was suspended in $10 \mathrm{~mm}-\mathrm{Tris} / \mathrm{HCl}, 50 \mathrm{~mm}-\mathrm{NaCl}$, $1.5 \mathrm{mM}-\mathrm{MgCl}_{2}, \mathrm{pH} \mathrm{7.5}$, and the detergents were added to a concentration of $0.2 \%$. The preparations were shaken at room temperature $(150$ r.p.m.) for $60 \mathrm{~min}$. The phosphatase activities were then determined in the preparations and in the supernatants after centrifugation at $27000 \mathrm{~g}$ for $5 \mathrm{~min}$ (Table 2). Deoxycholate, Zwittergent 3-14 and Brij 58 were the most effective for solubilizing the enzyme.

\section{pH optimum, $K_{m}$ and substrate specificities}

The activity of the purified phosphatase was determined at different $\mathrm{pH}$ values (pH 5 to $\mathrm{pH} 10)$. The profile ( $V_{\max } \mathrm{vs} \mathrm{pH}$ ) of the purified preparation was essentially the same as that obtained earlier with the crude enzyme (von Tigerstrom \& Stelmaschuk, 1985). Thus, the cell- 
Table 2. Solubilization of the cell-associated phosphatase with detergents

The experiment was done once.

\begin{tabular}{lclc}
\multicolumn{1}{c}{ Detergent } & $\begin{array}{c}\text { Percentage } \\
\text { of phosphatase } \\
\text { solubilized }\end{array}$ & \multicolumn{1}{c}{ Detergent } & $\begin{array}{c}\text { Percentage } \\
\text { of phosphatase } \\
\text { solubilized }\end{array}$ \\
None & 22 & CHAPS & 39 \\
Triton X-305 & 26 & Triton X-45 & 42 \\
Brij 38 & 30 & Triton X-100 & 58 \\
Triton X-35 & 31 & Brij 58 & 68 \\
Octylglucopyranoside & 33 & Zwittergent 3-14 & 85 \\
Triton X-57 & 37 & Deoxycholate & 86 \\
Cholate & 37 & &
\end{tabular}

Table 3. Substrate specificity of the cell-associated phosphatase

The activities were determined from three assays at 3,10 and $30 \mathrm{~min}$ of a suitably diluted purified enzyme preparation.

\begin{tabular}{|c|c|c|}
\hline \multirow[b]{2}{*}{ Substrate } & \\
\hline & $\mathrm{U} \mathrm{ml}^{-1}$ & $\%$ \\
\hline pNPP & $35 \cdot 2$ & 100 \\
\hline $5^{\prime}-\mathrm{AMP}$ & $48 \cdot 2$ & 137 \\
\hline 2'-AMP & $25 \cdot 0$ & 71 \\
\hline 3'-AMP & $24 \cdot 0$ & 68 \\
\hline ADP & $30 \cdot 6$ & 87 \\
\hline ATP & $36 \cdot 6$ & 104 \\
\hline 5'-GMP & $54 \cdot 2$ & 154 \\
\hline $2^{\prime}, 3^{\prime}-\mathrm{GMP}$ & $23 \cdot 6$ & 67 \\
\hline $5^{\prime}$-UMP & $50 \cdot 6$ & 144 \\
\hline $2^{\prime}, 3^{\prime}-$ UMP & $30 \cdot 3$ & 86 \\
\hline $5^{\prime}-\mathrm{CMP}$ & $44 \cdot 0$ & 125 \\
\hline 5'-dAMP & $51 \cdot 7$ & 147 \\
\hline 5'-dGMP & $54 \cdot 2$ & 154 \\
\hline 5'-dTMP & $42 \cdot 9$ & 122 \\
\hline $5^{\prime}-\mathrm{dCMP}$ & $44 \cdot 0$ & 125 \\
\hline$\alpha$-Glycerophosphate & $36 \cdot 6$ & 104 \\
\hline$\beta$-Glycerophosphate & 33.9 & 96 \\
\hline Glucose 6-phosphate & 40.8 & 116 \\
\hline
\end{tabular}

associated phosphatase is most active at $\mathrm{pH} 8.5$. The low activities at $\mathrm{pH} 9.5$ and 10 are in part a reflection of the instability of the enzyme under these conditions.

The $K_{\mathrm{m}}$ value for the enzyme was determined with pNPP as the substrate at concentrations from $0.05 \mathrm{mM}$ to $15 \mathrm{mM}$. The activity rose sharply until the concentration was about $2 \mathrm{~mm}$ and then increased slowly and nearly linearly up to $15 \mathrm{~mm}$-pNPP. Higher substrate concentrations were not used. Two $K_{\mathrm{m}}$ values, $0.56 \times 10^{-4} \mathrm{M}$ and $3.4 \times 10^{-4} \mathrm{M}$, were estimated from the reciprocal plot (Fig. 4). It appears that the enzyme continues to be slightly activated by increasing substrate up to very high concentrations. Attempts to overcome this effect by adding divalent metal ions and detergent to the assay solutions were not successful. Routine assays were done with 4 mM-pNPP. At this concentration the phosphatase was only $13 \%$ less active than with 15 mM-pNPP.

The phosphatase was routinely assayed in Tris/ $\mathrm{HCl}$ buffer with $\mathrm{pNPP}$ as the substrate. To determine the substrate specificity of the enzyme it was assayed with other phosphomonoesters in the presence of triethanolamine to avoid possible transphosphorylation reactions. The activities obtained with 18 different substrates were calculated from a linear rate of inorganic phosphate release (Table 3 ). The results indicated that the enzyme is non-specific with respect to 
Table 4. Effect of inhibitors on phosphatase activity

\begin{tabular}{llc}
\multicolumn{1}{c}{ Inhibitor } & $\begin{array}{c}\text { Concn } \\
(\mathrm{mM})\end{array}$ & $\begin{array}{c}\text { Inhibition } \\
(\%)\end{array}$ \\
Potassium phosphate & 1.0 & 30 \\
Sodium arsenate & 4.0 & 48 \\
& 1.0 & 41 \\
o-Phenanthroline & 4.0 & 73 \\
& 0.05 & 7 \\
8-Hydroxyquinoline & 0.5 & 58 \\
& 0.05 & 26 \\
EDTA & 0.5 & 99 \\
& 0.01 & 27 \\
& 0.02 & 57 \\
& 0.05 & 97
\end{tabular}

the substrate used. In general, all ribo- and deoxyribonucleoside 5 -phosphates were hydrolysed faster than pNPP. Ribonucleoside 2'- or 3'-phosphates were hydrolysed more slowly than pNPP. Glucose 6-phosphate and $\alpha$ - and $\beta$-glycerophosphates were hydrolysed at rates similar to pNPP.

\section{Inhibition and reactivation}

The enzyme was relatively insensitive to inorganic phosphate and arsenate but some chelating agents, especially EDTA and 8-hydroxyquinoline, were strongly inhibitory (Table 4). However, the addition of metal ions to the assay solution was not required for maximum activity unless the enzyme was first treated with a chelating agent.

It was, therefore, of interest to determine which metal ions could reactivate EDTA-inhibited phosphatase. To ensure maximum inhibition the enzyme was dissolved in a solution containing $0.2 \mathrm{mM}$-EDTA and then assayed in a solution containing the divalent metal ions at $0.05 \mathrm{mM}$. No activation was obtained with $\mathrm{NiCl}_{2}, \mathrm{FeSO}_{4}$ or $\mathrm{BaCl}_{2}$. The addition of $\mathrm{MgCl}_{2}, \mathrm{CaCl}_{2}, \mathrm{MnCl}_{2}$, $\mathrm{CoCl}_{2}$ and $\mathrm{ZnCl}_{2}$ caused reactivation of $4.6 \%, 7 \%, 14.5 \%, 24 \%$ and $66 \%$ of the enzyme activity, respectively. These results are in general agreement with earlier observations (von Tigerstrom \& Stelmaschuk, 1985) and suggest that the cell-associated phosphatase is a $\mathrm{Zn}^{2+}$-containing enzyme.

\section{DISCUSSION}

The cell-associated enzyme from L. enzymogenes resembles many other alkaline phosphatases in that it hydrolyses a number of phosphomonoesters, is most active at $\mathrm{pH} 8.5$ and is probably a $\mathrm{Zn}^{2+}$-containing metalloenzyme (McComb et al., 1979). The enzyme has a relatively high $K_{\mathrm{m}}$ for pNPP and is unusual in that it is a hydrophobic protein.

According to the results of SDS-PAGE, the $M_{\mathrm{r}}$ of the phosphatase or its active subunit is about 69000 . The fact that gel filtration indicated a much higher $M_{\mathrm{r}}$ could mean that the native enzyme is composed of subunits. However, the higher apparent $M_{\mathrm{r}}$ might be due to the presence of detergent during the gel filtration.

Although many bacterial phosphatases have been described (McComb et al., 1979), the cellassociated phosphatase of $L$. enzymogenes is of particular interest because of its hydrophobic nature and its tight binding to the outer membrane of the organism (von Tigerstrom \& Stelmaschuk, 1985). Very few enzymes are located in the outer membrane of bacteria (Lugtenberg \& Van Alphen, 1983). However, the phosphatases of Capnocytophaga ochracea and related species of anaerobic gliding bacteria have also been found to be partially associated with the outer membrane (Poirier \& Holt, 1983). The phosphatase from C. ochracea appears to be less hydrophobic than the enzyme from $L$. enzymogenes, though, since it can be eluted from ionexchange chromatography columns without detergent. When the $L$. enzymogenes enzyme was chromatographed without detergent only $8 \%$ of the phosphatase was recovered. 
The L. enzymogenes phosphatase described here has a much higher specific activity than other bacterial phosphatases (McComb et al., 1979). The specific activity is 1.6 times higher than that of the phosphatase from $L$. enzymogenes which is excreted into the medium (von Tigerstrom, 1984) and 60 times higher than the specific activity of the $C$. ochracea alkaline phosphatase (Poirier \& Holt, 1983).

Many of the characteristics of the cell-associated enzyme, such as its hydrophobicity, substrate specificity and $M_{\mathrm{r}}$, support the earlier conclusion that the enzyme is distinct from the excreted phosphatase of this organism (von Tigerstrom, 1984). Whether the two enzymes are related in amino acid composition or antigenicity remains to be determined.

Since the phosphatase is located outside the cytoplasmic membrane it probably has a nutritional function and may work in cooperation with the excreted phosphatase to degrade phosphomonoesters in the environment. The enzyme is probably held in the outer membrane by hydrophobic interaction with other envelope components. However, it is more readily released from the outer membrane by detergent treatment than are a number of major outer membrane proteins (R. G. von Tigerstrom \& T. A. Solleveld, unpublished).

The substrates do not have free access to the active site of the enzyme from the exterior of the organism, since intact cells have low phosphatase activity. However, treatment of the cells with toluene, an agent which disrupts membrane function but does not solubilize the enzyme, leads to nearly full expression of the enzyme activity (von Tigerstrom, 1984). Thus, the active site may face the periplasm or the enzyme may be partially covered by slime or capsular material. We have now raised antibodies to the enzyme and with these the position of the phosphatase in the outer membrane and its interaction with other outer membrane components can be investigated in more detail.

This work was supported by the National Sciences and Engineering Research Council of Canada.

\section{REFERENCES}

AMES, B. N. (1966). Assay of inorganic phosphate, total phosphate and phosphatases. Methods in Enzymo$\log y$ 8, 115-118.

Christensen, P. \& CoOK, F. D. (1978). Lysobacter, a new genus of non-fruiting gliding bacteria with a high base ratio. International Journal of Systematic Bacteriology 28, 367-393.

Fairbanks, G., Steck, T. L. \& Wallach, D. F. H. (1971). Elecrophoretic analysis of major polypeptides of the human erythrocytic membrane. Biochemistry 10, 2606-2616.

LUGTENBERG, B. \& VAN AlPHEN, L. (1983). Molecular architecture and functioning of the outer membrane of Escherichia coli and other gram-negative bacteria. Biochimica et biophysica acta 737, 51-115.

MCCOMB, R. B., BOWERs, G. N., JR \& POSEN, S. (1979). Alkaline Phosphatase. New York: Plenum Publishing Corp.

MaizeL, J. V., JR (1971). Polyacrylamide gel electrophoresis of viral proteins. Methods in Virology 5, 179-246.

PoIrier, T. P. \& HolT, S. C. (1983). Acid and alkaline phosphatases of Capnocytophaga species. II. Isolation, purification, and characterization of the enzymes from Capnocytophaga ochracea. Canadian Journal of Microbiology 29, 1361-1368.

REICHENBACH, H. (1981). Taxonomy of the gliding bacteria. Annual Review of Microbiology 35, 339364.

ReichenbaCh, H. \& Dworkin, M. (1981). The order Cytophagales (with addenda on the genera Herpetosiphon, Saprospira, and Flexithrix). In The Prokaryotes, pp. 356-379. Edited by M. P. Starr, H. Stolp, H. G. Trüper, A. Balows \& H. G. Schlegel. New York: Springer-Verlag.

VON TigERSTROM, R. G. (1980). Extracellular nucleases of Lysobacter enzymogenes: production of the enzymes and purification and characterization of an endonuclease. Canadian Journal of Microbiology 26, 1029-1037.

VON TIGERSTROM, R. G. (1981). Extracellular nucleases of Lysobacter enzymogenes: purification and characterization of a ribonuclease. Canadian Journal of Microbiology 27, 1080-1086.

vON TIgERSTROM, R. G. (1983). The effect of magnesium and manganese ion concentrations and medium composition on the production of extracellular enzymes by Lysobacter enzymogenes. Journal of General Microbiology 129, 2293-2299.

von Tigerstrom, R. G. (1984). Production of two phosphatases by Lysobacter enzymogenes and purification and characterization of the extracellular enzyme. Applied and Environmental Microbiology 47, 693-698.

von Tigerstrom, R. G. \& Stelmaschuk, S. (1985). Localization of the cell-associated phosphatase in Lysobacter enzymogenes. Journal of General Microbiology 131, 1611-1618.

WARBURG, O. \& ChRistian, W. (1941). Isolierung und Kristallisation des garungsferments Enolase. Biochemische Zeitschrift 310, 384-421.

WhITAKER, D. R. (1970). The $\alpha$-lytic protease of a myxobacterium. Methods in Enzymology 19, 599613. 